\title{
Hıristiyanlık Karşıtı Yahudi Reddiye Geleneğinde İronik Bir Mektup: Al Tehi Ke-Avoteyha (Atalarına Benzeme)
}

\author{
Fatma Seda Şengül \\ Arş. Gör., Bursa Uludağ Üniversitesi, İlahiyat Fakültesi, Dinler Tarihi Ana Bilim Dalı \\ Bursa/Türkiye \\ fatmasedagurbetoglu@gmail.com \\ http://orcid.org/0000-0001-7641-1541
}

\begin{abstract}
Öz: Bu çalışmada Orta Çă̆ Yahudi-Hıristiyan reddiye geleneği açısından hem kendi dönemindeki hem de kendinden sonraki polemikçilere içerik ve yöntemsel açıdan katkı sağlamış olan Al Tehi Ke-Avoteyha Risalesi konu ve analiz edilmiştir. Profiat Duran'a (ö. 1415) ait bu risalenin aslı, kendisi gibi zorunlu olarak vaftiz edilen, fakat yeni dininde kalmakta ssrarc1 olan arkadaşı David Bonet Bonjorn'a yazılmış bir mektuptur. Mektubu, Yahudi-Hıristiyan reddiye geleneğinde özgün kılan ve günümüze ulaşmasını sağlayan saiklerden ilki eserde kullanılan yöntemdir. Duran, Yahudi inançları ile irrasyonel bulduğu Hıristiyan inançları (Teslis, aslî günah-aslî günahtan kurtuluş, enkarnasyon, töz dönüşümü) arasında yaptığ1 karşılaştırmada bilimsel (fizik) ve felsefî (mantık ve metafizik) argümanları kullanmayı tercih etmiştir. Mektubun ikinci önemli özelliği ise, eserdeki eleştirel tavrın diğer reddiyelerden farklı olarak, gizli alay ve imalar içeren ironik bir üslupla okuyucuya sunulmuş olmasıdır. Duran'ın kişisel tecrübesinden yola çıkılarak hazırladığı bu metin günümüze kadar gelebilmiş ve kendi dönemindeki Yahudi-Hıristiyan ilişkilerine hem dinî hem de sosyal açıdan bir bakış imkânı sağlamıştır.
\end{abstract}

Anahtar Kelimeler: Dinler Tarihi, Al Tehi Ke-Avoteyha, Atalarına Benzeme, İbranice Mektup, Profiat Duran, Reddiye, Yahudi-Hiristiyan.

Geliş Tarihi/Received Date: 09.09.2021

Kabul Tarihi/Accepted Date: 06.12.2021

\section{Araştırma Makalesi/Research Article}

Atıf/Citation: Şengül, Fatma Seda. "Hıristiyanlık Karşıtı Yahudi Reddiye Geleneğinde İronik Bir Mektup: Al Tehi Ke-Avoteyha”. Uludağ Üniversitesi İlahiyat Fakültesi Dergisi 30/2 (Aralık 2021), 423-441.

https://doi.org/10.51447/uluifd.1021071 


\title{
An Ironic Letter in The Anti-Christian Jewish Polemic Tradition: Al Tehi Ka-Avotekha (Be Not Like Fathers)
}

\begin{abstract}
This study deals with the epistle called Al Tehi Ka-Avotekha, which has contributed in terms of content and method to the polemicists both in his period and after it in the medieval Judeo-Christian polemic tradition. This treatise is originally a letter written by Profiat Duran (d. 1415) to his friend David Bonet Bonjorn, who, like Duran, was forced to be baptized but insisted on staying in his new religion. The method used in the work is the first of the motives that make the letter original (in the Jewish-Christian polemic tradition) and enables it to reach today. Duran preferred to use scientific (physical) and philosophical (logical and metaphysical) arguments in the comparison he made between Jewish beliefs and Christian beliefs (Trinity, original sin-liberation from original sin, incarnation, transubstantiation) that he found irrational. The second important feature of the letter is that, unlike other refutations, the critical attitude in the work is presented to the reader in an ironic style that includes hidden sarcasm and allusions. This text, which Duran prepared based on his personal experiences, has survived to the present day and provided the opportunity to evaluate Judeo-Christian relations from both a religious and social perspective.
\end{abstract}

Keywords: History of Religions, Al Tehi Ka-Avotekha, Be Not Like Fathers, Hebrew Letters, Profiat Duran, Polemic, Jewish-Christian.

[You may find an extended abstract of this article after the bibliography.]

\section{Giriş}

Yahudi-Hıristiyan reddiye geleneğinde özel bir yazı türü olarak değerlendirilen mektuplar arasında en meşhurları Joshua Lorki'ye (ö. 1419) ait Nusah ha-Ktav ve Duran'a ait Al Tehi Ke-Avoteyha'dır. Her iki mektubun muhatabı da Yahudi iken H1ristiyanlığa geçen kimselerdir ve dolayısıyla karşısındaki kişiyi Yahudiliğin gerçek din olduğuna ikna etme çabasıyla yazılmıştır. Ayrıca bu mektuplar kendi dönemi ve sonrasında daha geniş bir kitleye hitap edecek şekilde Hıristiyanlık karşıtı Yahudi reddiyeleri arasında da kendine yer bulmayı başarabilmiştir. ${ }^{1}$ Dönemin YahudiHıristiyan ilişkilerine dair çeşitli kodlar barındıran Duran'ın mektubu ve bu metnin günümüze kadar uzanan yolculuğu, üslup ve içeriği, Hıristiyanlara yönelttiği eleştiriler ve muhtemel Hıristiyan cevaplar çalışmamız boyunca yol haritamızı belirleyen ana unsurlardir.

14. yüzyılın önde gelen reddiye yazarlarından biri olan Profiat Duran'ın (İbranice adı Yitshak ben Moşe ha-Levi) 1340-1360 tarihleri arasında doğduğu düşünül-

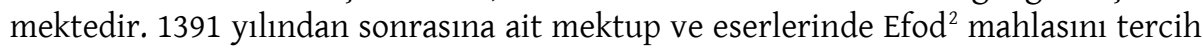

1 Daniel J. Lasker, Jewish Philosophical Polemics against Christianity in the Middle Ages (Oxford: Littman Library Of Jewish Civilization, 2007), 17, 20, 21.

2 Duran bu mahlası yalnızca Katalanca adının (Profiat Duran) ilk harflerinden oluşan basit bir kısaltma olarak değil, İspanya'da artan Yahudi karşıtlığı nedeniyle de tercih ettiğini kendi eserinde 
ettiği için bu adla tanınırlığı daha fazladır. Doğum yeri hususunda bazı ihtilaflar bulunsa da Perpignan şehrine ait arşiv kayıtlarından babası ve dedesinin Perpignan Yahudilerinden olduğu ve ömrünün kayda değer bir kısmını burada geçirdiği anlaşılmaktadır. Çocukluk ve gençlik döneminde köklü bir din eğitimi almış ve bu eğitimine tıp, astronomi, tarih, matematik, dil bilgisi (bilhassa İbranice) gibi alanları da ekleyerek kendini yetiştirmiş ve bu alanlarda çeşitli eserler hazırlamıştır. Konuşma dili bölgenin yerel dili olan Katalancadır fakat eserlerini İbranice olarak kaleme almıştır. Tanah'ın İbranice metni/grameri noktasında uzun yıllar boyunca çalıştı̆̆ bilinmektedir. İyi derecede Latince bildiği düşünülmektedir. İbranice ve Latinceye dair bu donanımı neticesinde eserlerinde Vulgate'da tespit ettiği çeviri hatalarına yer verdiği görülmektedir. Duran'ın çok sayıda eseri olmasına karşın, kendi döneminde ve sonrasında çokça tesiri bulunan meşhur üç eseri bulunmaktadır. Bunlardan ilki bir gramer kitabı olan Maase Efod adlı eseridir. Diğer iki eseri ise, Yahudi reddiye literatüründe iki ayrı kategoride ${ }^{3}$ adları zikredilen Hıristiyanlık karşıtı İggeret Al Tehi Ke-Avoteyha (Atalarına Benzeme Risalesi) ve Kelimmat ha-Goyim (Goyların Utanc1)'dir.

Çalışmamızın odak noktası olan Al Tehi Ke-Avoteyha'nın ${ }^{4}$ Duran'ın tanınırlığını sağlayan asıl metin olduğu iddia edilmektedir. Duran'ı ve eserini seçmemizde iki unsur etkili olmuştur. İlki, genel anlamda diğer Yahudi polemikçilerden farklı olarak, yaşadığı coğrafyadaki Yahudi karşıtı hareketler neticesinde zorunlu vaftize uğramış bir Yahudi yazar olmasıdır. Perpignan arşivlerindeki kayıtlar dikkate alındığında 1391 yılının sonlarında ya da daha güçlü ihtimalle 1392 yılının ilk aylarında kendi isteği dışında vaftiz edilerek Hıristiyanlaștırılmıștır. Vaftiz olduktan sonra Honoratus de Bonafide Latince adını aldığı ve bu adla da kayıtlarda kendisinden bahsedildiği bilinmektedir. ${ }^{5}$ Hem yaşanan süreç (bilhassa bölgedeki YahudiHıristiyan ilişkileri açısından) hem de reddiyelerin Hıristiyan iken yazılmış olabileceği ihtimali/tartışmaları oldukça dikkat çekicidir. ${ }^{6}$ Çünkü Duran Yahudi karşıtlığı-

(Heşev ha-Efod) belirtmektedir. Duran'ın Efod mahlası ile ilgili ayrıntılı bilgi için bk. Frank Talmage, “The Polemical Writings of Profiat Duran”, Immanuel 13 (1981), 72.

3 Kelimmat ha-Goyim, Hıristiyan öğretilerinin Yeni Ahit öğretileriyle karşılaştırıldığı reddiye kategorisine dahil edilen bir metindir. İggeret Al-Tehi Ke-Avoteyha ise Hıristiyanlı̆̆ın felsefe, mantık, fizik, metafizik gibi ilim dallarıyla alenen çelişen yönlerinin yazıya döküldüğü metinler kategorisinde yer almaktadır. Lasker, Jewish Philosophical Polemics against Christianity in the Middle Ages, 19, 20.

4 Çalışma içerisinde Kobler'in İngilizce çeviri metni esas alınmıştır. Franz Kobler, "Be Not Like Fathers", Letters of Jews through the Ages: From Biblical Times to the Middle of the Eighteenth Century (New York: East and West Library, 1978), 276-282; Mektubun pek çok edisyon dikkate alınarak hazırlanan ve en muteber kabul edilen İbranice edisyonu için bk. Profiat Duran, Kitvey Pulmus Le-Profiat Duran, ed. Frank Talmage (Kudüs: The Zalman Shazar and The Dinur Center, 1981), 73-83.

5 Hanne Trautner-Kromann, Shield and Sword: Jewish Polemics against Christianity and the Christians in France and Spain from 1100-1500 (Tübingen: Mohr Siebeck, 1993), 155; Richard W. Emery, "New Light on Profayt Duran “The Efodi”', The Jewish Quarterly Review 58/4 (1968), 333.

6 Meşhur tarihçi Baer'e göre Duran zorunlu vaftizden kaçmış ve ömrünün sonuna kadar da vaftiz 
nın kademe kademe yükseldiği bir tarih aralı̆̆ında yaşamıştır. Dönemin şartları gereği bir Yahudinin Hıristiyanlık karşıtı bir metin yazmasından daha fazla dikkat ve tepki çekecek olan husus, gönüllü ya da gönülsüz Hıristiyan olmuş bir Yahudinin yeni dinine yani Hıristiyanlık aleyhine yazılar yazmasıdır.

İkinci önemli etken ise, Al Tehi Ke-Avoteyha'nın Duran'ın en eski eseri ${ }^{7}$ olmasına rağmen içerik ve üslup bakımından oldukça sıra dişı, veciz ve gösterişli olmasıdır. $\mathrm{Bu}$ hâliyle eser deneyimsiz bir yazar çalışmasına benzememektedir. Metninde reddiye geleneğinde (bilhassa Yahudi reddiyelerinde) farklı bir türün doğmasına yol açan ironik bir dil tercih etmiştir. Karşı tarafın dinî tercihini över gibi görünen fakat hakikatte eleştirmeye ve yer yer alay etmeye dayalı, edebî bir üsluba sahip bir metin görünümündedir. Bu bakımdan eser, Orta Çă̆ İbrani dili açısından oldukça

edilmeden bir Yahudi olarak yaşamıştır. 1414-1415 yıllarında Yahudiler ve Hıristiyanlar arasında Tortosa'da yapılan dinî tartışmada Yahudi tarafta yer alabilmesi buna delil gösterilmektedir. Üstelik din değiştirmiş/konverso iken bu reddiyeleri kaleme alması da mümkün değildir. Emery’ye göre ise Perpignan arşivinin referansıyla Duran'ın vaftiz olduğu kesinleşmiştir (3 Şubat 1391-1 Mayıs 1392 tarihleri arasında bir vakitte). Belgelerde vaftiz olduktan sonra aldığı Latince isimden dahi bahsedilmekte ve sonraki yıllarda bu isimle hayatına devam ettiğine dair referanslar bulunmaktadır. Bunlardan en önemli olanı Aragon Kralı I. Juan'a Honoratus de Bonafide adında birinin astrolog olarak hizmet verdiği bilgisidir. Duran'ın reddiyelerini din değiștirmeden önce mi yoksa sonra mı yazdığ1na dair çeşitli tartışmalar mevcuttur. Hıristiyan olduktan sonra yazdığı hâlde vaftiz öncesinde yazmış gibi gösterebilmesi, konversolara dair yaptırımların henüz bölgede yeterince sert bir istikamette seyretmediğinin bir göstergesi olarak düşünülebilir. Nitekim Salihoğlu'na göre ilk nesil konversolar/marranolar sonraki kuşaklardan daha özgür bir ortamda yaşamışlardır. Dolayısıyla kendi dinlerini Hıristiyanlık ile karşılaştırma (sözlü/yazılı) imkânına daha fazla sahiptiler. Zira sonraki nesiller engizisyona tabi tutulacağından ilk nesil kadar rahat davranamamışlardır. Kanaatimizce Duran da bu nispeten olumlu hava neticesinde eserlerini yazabilmiş ve dolaşıma sokabilmiştir. Duran'ın vaftizi ve eserlerinin yazılış tarihleri hususunda ayrıntılı bilgi ve konuya dair tartışma için bk. TrautnerKromann, Shield and Sword, 157, 158; Yitzhak Baer, A History of the Jews in Christian Spain, Vol. 2: From the Fourteenth Century to the Expulsion, çev. Louis Schoffman (Skokie: Varda Books, 2001), 152; Emery, “New Light on Profayt Duran 'The Efodi”, 329, 331-335; Maud Kozodoy, The Secret Faith of Maestre Honoratus: Profayt Duran and Jewish Identity in Late Medieval Iberia (Philadelphia: University of Pennsylvania Press, 2015), 21-27, 30-33; Fatma Seda Şengül, “Yahudi Düşünür Profiat Duran'ın İsa'nın Ulûhiyetine Dair Eleştirileri”, Oksident 1/1 (2019), 84, 85; Mahmut Salihoğlu, "Marranolar ve Dini İnançları”, EKEV Akademi Dergisi 15/49 (Güz 2011), 113.

7 Mektubun yazılış tarihine ilişkin pek çok tartışma vardır. Bütün tespit ve iddialar dikkate alındığında kanaatimizce 1392 Mayısından sonraki bir tarih ile 1394/1395 tarihleri arasında yazılmış olması mümkündür. Vaftiz edildikten sonra yazılmış olma gerekliliği ve Al Tehi Ke-Avoteyha'dan sonra yazıldı̆̆ından emin olunan Kelimmat ha-Goyim adlı eserin yazılış tarihinin (1396) bilinmesi bizde bu kanaatin hasıl olmasına neden olmuştur. Mektubun yazılış tarihine ilişkin bilgi ve tartışma için bk. Talmage, "The Polemical Writings of Profiat Duran”, 74; Trautner-Kromann, Shield and Sword, 157, 158; Kozodoy'a göre zorunlu vaftizden üç yıl kadar sonra bu eseri yazmıştır. Kozodoy, The Secret Faith of Maestre Honoratus, 22, 115; Emery, "New Light on Profayt Duran 'The Efodi”', 333-335. 
kıymetli görülmekte ve dönemin yazı dilinde nadir rastlanan bir üsluba sahip olduguundan, klasikler arasında zikredilmektedir. Duran'ın bu çalışmasının kendi döneminde ve sonrasında Hasday Crescas (Bitul İkkarey ha-Notsrim), Şem Tov ibn Şaprut (Even Bohan), Yosef Albo (Sefer ha-íkkarim), David Nasi (Hodaat Baal Din) gibi önde gelen Yahudi polemikçi ve yazarları oldukça etkilediği bilinmektedir. ${ }^{8}$

\section{Mektubun Yazılış Gerekçesi, Üslubu ve İçeriği}

Duran'ın eserinin orijinali, kendisi gibi zorla vaftiz edilen genç hekim arkadaşı David Bonet Bonjorn/Bongoran'a ${ }^{9}$ yazılan bir mektuptur. Mektubun el yazma nüshalarından birinin ön kısmında yazılış maksadı şöyle anlatılır: Yahudiliğe geri dönmek isteyen iki arkadaş (Duran ve David), Filistin'e kaçmaya karar verirler. Yolculuk öncesinde David, Avignon'da kendisi de sonradan Hıristiyanlığa geçmiş olan Pavlus de Sancta Maria ${ }^{10}$ ile karşılaşır ve ikna edilerek gerçek anlamda Hıristiyan olmaya karar verir. Dolayısıyla David, Filistin'e gitmekten vazgeçer ve yolculuğa çıkacakları gün buluşmaya gelmez ve kendisi Duran'a verilmek üzere bir mektup gönderir. Bu mektubun orijinali ve akıbetine ilişkin herhangi bir bilgiye rastlanılamamıştır. Duran'ın bu mektuba yazdığı karşılıktan içeriğe dair birtakım tespitler yapmak mümkündür. Muhtemelen mektubunda Pavlus de Sancta Maria'nın kendisini ikna ettiğini, Hıristiyanlık dininde kalacağını ve arkadaşına da yeniden Yahudiliğe dönmemesini tavsiye etmiştir. Baer gibi bazı tarihçilere göre bu rivayet, olayın vuku bulmasından çok sonra bazı varsayımlar üzerinden kurgulanmış olsa da araştırmacılar tarafından dikkate alınmaya değer bulunmaktadır. ${ }^{11}$

Duran arkadaşından aldığı bu mektuba bir cevap yazar ve bu mektup Duran'in yaşadığ 1 dönemde ve sonrasında çokça kopyalanır. Bu husustaki en yaygın rivayete göre Duran'ın bizzat kendisi Kastilya Krallı̆̆ı'ndaki bütün Yahudilerin cemaat önderi olan Don Meir Alguadex'e mektubun bir kopyasını göndererek tanınması için

8 Baer, A History of the Jews in Christian Spain, Vol. 2, 152; Trautner-Kromann, Shield and Sword, 157; Talmage, "The Polemical Writings of Profiat Duran", 85.

9 Perpignan kayıtlarına göre David, Bonet David Bonjorn'un oğludur. Kayıtlardaki referanslardan yapılan tarihsel çıkarıma göre Profiat Duran'dan çok daha genç olduğu düşünülmektedir. Duran'ın kendisine hocalık yapmış olabileceği de ihtimaller arasındadır. Emery, "New Light on Profayt Duran ‘The Efodi”', 328 (Dipnot 3).

10 Hıristiyanlığa geçmeden önceki adı Solomon ha Levi'dir. Hıristiyan olduktan sonra Papa'ya yakınlığıyla bilinen bazı din adamlarının desteği sayesinde 1415 yılında Burgos piskoposluğu görevine getirilmiştir. Eğitimi ve etkinliğini zaman içinde arttırdığı ve Yahudiler aleyhinde somut adımlar atılmasında önayak olduğu aktarılmaktadır. Bu minvalde Kral'dan Yahudi ve Hıristiyanlar arasında bir münazara düzenlenmesini isteyecek kadar nüfuz elde etmiştir. Bununla birlikte çeşitli gerekçelerle taleplerinin tam olarak gerçekleşmediği görülmektedir. Talmage, "The Polemical Writings of Profiat Duran", 73, 74; Baer, A History of the Jews in Christian Spain, Vol. 2, 155.

11 Kobler, "Be Not Like Fathers", 276; Baer, A History of the Jews in Christian Spain, Vol. 2, 150, 151; Talmage, "The Polemical Writings of Profiat Duran", 73. 
ilk adımı atmıştır. Mektubu basan/yayımlayan ilk kişinin Yitshak Akriş olduğu düşünülmektedir. ${ }^{12}$ Mektubun ön kısminda Yosef ben Şem Tov'a (öl. 1480) ait bir şerh bulunmaktadır. Akriş’ten nakledildiğine göre içerikteki istihzalı ve muğlak ifadelerden dolayı başlangıçta Hıristiyanlar metnin Hıristiyanlık lehinde bir çalışma olduğunu düşünmüşler ve metni her bölümün baş kısminda geçen al tehi keavoteyha (Atalarına Benzeme) ifadesinden dolayı (bozulmuş bir ses benzerliği ile) Latince Alteca Boteca olarak isimlendirmişler ve bu çalışmayı kendi inançlarının lehinde kullanmaya çalışmışlardır. Fakat Yosef ben Şem Tov'un, Duran'ın asıl maksadının David'le ve yeni dini olan Hıristiyanlıkla alay etmek olduğunu yazması ve içeriğine dair yaptığı şerhin dolaşıma girmesinden sonra hakikatin anlaşıldığı düşünülmektedir. $\mathrm{Bu}$ süreçte Hıristiyanların tespit edebildikleri nüshaları toplayıp halkın önünde yaktığı da iddialar arasındadır. Her iki iddianın (Hıristiyanların metni yanlış değerlendirmesi ve Yosef ben Şem Tov sayesinde hakikatin açı̆̆a çıkması) gerçekliği de tartışmalıdır. Zira metnin alaycı dilinin biraz dikkatli bir okumayla, aslında yazarın denildiği kadar gizli imalarda bulunmadığı, Hıristiyanları tahkir ettiği rahatlıkla anlaşılmaktadır. ${ }^{13}$ Kanaatimizce bu husustaki en önemli delil, Duran'ın metnin sonlarında Yahudilikten ayrılmayacağına dair ssrarlı tavrı olmalıdır. $\mathrm{Bu}$ tavır görüldükten sonra metnin Hıristiyanlık lehinde bir çalışma olarak değerlendirilme ihtimali ortadan kalkmaktadır. Dolayısıyla söz konusu rivayetlerin daha sonradan uydurulmuş olması oldukça muhtemel gözükmektedir. Zira Hıristiyanlara ilişkin bu yanlış anlama meselesine yalnızca Yahudi kaynaklarında rastlanılması, mektuptaki alaycı üslubun mektupla ilgili bahislerde de sürdürülmeye devam ettiğini düşündürmektedir.

Metindeki parodiye dayalı kurguda Duran sıklıkla iki ifade kullanmaktadır. Değindiği her bir konunun öncesinde, al tehi ke-avoteyha (atalarına benzeme) demekte ve aslında ironik bir dille geçmişte yaşamış Yahudi peygamber/ataların hepsinin yanlış yolda olduğunu David'in ise (onlara benzemeyerek/onlar gibi yapmayarak) Hıristiyanlığı seçmek suretiyle onların yanılgısına düşmediğini belirtmektedir. Bir nevi eskiden inandığı din ile yeni mensubu olduğu din arasında bir karşılaştırma yapmaktadır. Duran'ın hem metin içinde sıklıkla kullandığı hem de risalesine üst

12 Mektubun ilk kez Akriş tarafından (ve İstanbul'da) basıldığı noktasında araştırmacılar hemfikirdir. Fakat basım tarihi noktasında bir belirsizlik söz konusudur. Kozodoy 16. yüzyılda basıldığını belirtir ve açık bir tarih vermezken, Kobler 1554 olarak açık tarih vermektedir. Meral'in 1493-1729 tarihleri arasında İstanbul Yahudi matbaalarında basılan bütün eserleri zikrettiği çalışmasında Al Tehi KeAvoteyha'nın 1577 yılında başka eserlerin de içerisinde bulunduğu bir koleksiyonda (İggeret Ogeret) Şlomo ve Yosef Ya'bets Matbaası'nda basıldığı kaydedilmiştir. Kozodoy, The Secret Faith of Maestre Honoratus, 248 (Dipnot 2); Yasin Meral, İbrahim Müteferrika Öncesi İstanbul'da Yahudi Matbuatı (14931729) (Ankara: Divan Kitap, 2016), 187; Kobler, “Be Not Like Fathers”, 282.

13 Meyer Kayserling, "Profiat Duran”, Jewish Encyclopedia (Erişim 1 Aralık 2021); Trautner-Kromann, Shield and Sword, 157; Talmage, "The Polemical Writings of Profiat Duran", 73, 75, 76; Kobler, "Be Not Like Fathers", 282. 
başlık olarak tercih edilen bu tabir sıradan bir ifade değil, bir Tanah alıntısıdır. ${ }^{14}$ Yahudi polemikçilerin eser adlarında buna benzer Kutsal Kitap pasajlarını kullanmaları yaygındır. İkinci ifade ise, her paragraf başında atalarının düştüğü "yanılgılar" David'e bildirildikten sonra, ata lo ken (sen böyle değilsin/sen böyle yapma!) denmekte ve akabinde Hıristiyanlık dini bakımından inanılması daha "makul" olan hususlar bildirilmektedir. Bu iki ifadenin (atalarına benzeme-sen böyle değilsin/sen böyle yapma!) düzenli ve sık kullanımı metnin üslubuna edebî bir hava katmaktadir.

Son yıllarda Duran ve eserleri üzerinde yapılan ayrıntılı çalışmalar neticesinde, yazarın Al Tehi Ke-Avoteyha'daki uslubunda Latince bir mektuptan esinlenmiş olabileceğine dair bazı iddialar söz konusudur. Pierre d'Alilly'ye isnat edilen metin (Epistola Diaboli Leviathan ${ }^{15}$ ile Duran'ın mektubu arasında bazı benzerlikler keşfedilmiştir. Her iki metinde de kinayeli bir dil, Kutsal Kitap'tan referanslar vermek suretiyle argümanı güçlendirme teşebbüsleri, rasyonel argümanlara başvuru şekilleri bulunmaktadır. Kozodoy'a göre Duran'ın bu eseri görüp hem içerik hem de üslup bakımından ondan etkilenmiş olması ihtimal dâhilindedir. Zira o tarihler Fransa ve Perpignan arasındaki irtibatın yoğun olduğu yıllar olarak bilinmektedir. ${ }^{16}$ Bununla birlikte bu esinlenme ihtimalinin Duran'ın özgünlüğüne ve çalışmasının kalitesine halel getirmeyeceği, aksine onu sonraki yüzyıllarda hızla yayılıp büyüyecek olan kültürel ağın (sahte övgü-hicivle karışık eleştiri) bir parçası hâline getirdiği için oldukça önemli bir tespit olduğunu düşünenler de vardır. ${ }^{17}$

Mektubun genel akışına göre Duran, öncelikli olarak Yahudi peygamberlerin, ataların, entelektüellerin kurtuluş ve cenneti kazanma adına tercih ettikleri yolları aktarır ve David'i onlara benzememesi için ikaz eder. Daha sonra ise, David'in ve onun gibi düşünen Hıristiyanların her ne kadar akıl, mantık, felsefe gibi temel ilkeleri reddetmiş olsalar da yalnızca imanla kurtuluşu savunarak ve yalnızca Mesih'e (İsa'ya) inanarak kurtuluşa ereceklerinden dolayı sevincini sahte bir övgüyle belirterek devam eder. Bu kurgu içerisinde Duran, genel olarak Hıristiyanlıktaki teslis, enkarnasyon, aslî günah/aslî günahtan kurtuluş, transubstantion (töz dönüşümü)* doktrinlerini eleştirmektedir. Bunlardan başka, kendi yaşadıkları dönem içerisinde Kilise'nin yaşadığı krizi (Büyük Bölünme 1378-1417) de gündeme taşıyarak Hıristi-

14 Zekeriya 1:4, II. Tarihler 30:7. Her iki pasajda Al Tihyu Ke-Avoteyhem (Atalarınıza Benzemeyin) şeklinde çoğul formda geçmektedir. Duran ise metninde doğrudan David'i hedef aldığı için Al Tehi KeAvoteyha (Atalarına Benzeme) şeklinde tekil formda zikretmektedir.

15 İngilizce çevirisi için bk. Irwing R. Raymond, “D’Ailly’s ‘Epistola Diaboli Leviathan”, Church History 22/3 (1953), 181-191.

16 Kozodoy, The Secret Faith of Maestre Honoratus, 124, 125.

17 Ryan Szpiech, "Between Court and Call: Catalan Humanism and Hebrew Letters", eHumanitsa-IVITRA 1 (2012), 174.

* Katolik öğretideki, ekmek ve şarabın tözsel bir değişikliğe uğrayarak İsa'nın bedeni ve kanına dönüşmesi. 
yanların kafa karışıklığını hatırlatmakta ve Yahudi şeriatına bağlılık noktasında Hıristiyanların İsa ve havarilerin izlediğinden farklı bir tutum sergilediğine dikkat çekmektedir.

\section{Hıristiyanlığa Yönelik Eleştiriler}

Duran, her ne kadar mektubunda Hıristiyan olma noktasında ikna olduğunu belirtmiş olsa da David'in zihninde oluşabilecek şüphe ve endişelerin farkındadır. Bu minvalde metnin genelinde ona akıl ve Tevrat yerine, salt imanı salık veren bir dini tercih ettiğini hatırlatmaktadır. Aklın kendisini bu yeni dine karşı sürekli uyarmaya çalıştığını fakat David'in buna kanmaması gerektiğini belirterek ironik üslubuna başlangıç yapmaktadır. Duran'a göre David bu yeni dine tabi olduğunu bildirerek, aklın ne derece tehlikeli olduğunu fark etmiş olmalıdır. Dolayısıyla David aklına karşı çok dikkatli olmalı ve kurtuluşu için sadece imanın "yeterli" olacağını her daim hatırında tutmalıdır. Bu hususta Duran Hiristiyanların kendilerine Tanah'1 referans almalarına gönderme yapmak suretiyle kendisi de Habakkuk'tan (2:4) bir alıntı yapmaktadır: '... doğru olan imanıyla yaşayacaktır. ${ }^{18}$

Duran, mektubunda, akıldan yoksun bir imanı alaylı bir dille takdir etmiş görünmektedir. Bu husustaki gerçek düşüncesini Maase Efod adlı eserinden anlamak mümkündür. Eserinde hakikati anlatırken, bilhassa inancın temellerini (heretiklere ve septiklere karşı) sağlamlaştırmak için felsefeyi ve onun alt dallarını kullanmanın ne kadar önemli olduğunu vurgulamaktadır. Bununla örtüşecek şekilde mektubunun önemli bir kısmını felsefî argümanlara dayalı bir düzlemde kurgulamıştır. Burada dikkat çekici olan husus ise akla ve mantığa aykırı olan inançların olumlu, fakat akla hitap eden inançların ise olumsuz olarak resmedilecek şekilde ironik bir tablo oluşturulmasıdır. ${ }^{19}$

Duran'ın mektubunda, akıl ve mantık ilkeleri ile ters düşen ve Hıristiyanların da ihtilaflı oldukları konuları ağırlıklı olarak tercih ettiğini söylemek mümkündür. Bu minvalde zikredilebilecek en temel eleştiri Teslis'tir. Duran, atalarının Şema Yisrael'de ${ }^{20}$ geçen teklik ifadesini basit anlamıyla anlayarak tek bir Tanrı'ya inandıklarını belirttikten sonra, David'in kendisini bu yanılgıdan kurtardığından bahsetmektedir. Tevhidin yerine, Hıristiyan öğretideki üçlü birliğin daha "doğru" olduğunu hissettiren Duran, Teslis'i yalın hâliyle, üçün bire, birin de üçe eşit görülmesi olarak izah eder. Öğretinin bu şekliyle matematik ve mantık ilkelerini ihlal ettiği aşikârdır. Dolayısıyla okuyucuya bir nevi izaha gerek yoktur, mesajı vererek irrasyonel olanı rasyonel olana tercih etmedeki absürtlüğü ortaya koymaktadır. ${ }^{21}$ Aynı şekilde Tes-

18 Kobler, "Be Not Like Fathers”, 277.

19 Talmage, “The Polemical Writings of Profiat Duran”, 71, 75, 76.

20 “Dinle Yisrael! Ha-Şem Tanrımız'dır, Ha-Şem Bir'dir.” Tesniye 6:4.

21 Maud Kozodoy, "The Hebrew Bible as Weapon of Faith in Late Medieval Iberia: Irony, Satire and Scriptural Allusion in Profiat Duran's Al Tehi ka-Avotekha”, Jewish Studies Quarterly 18/2 (2011), 188, 
lis'in Mantık ilminin en temel ilkesini (kıyas) ihlal ettiğini de hatırlatmaktadır. Bu doğrultuda Duran; “Baba, Tanrı'dır. Tanrı Oğul'dur. O hâlde Baba, Oğul'dur” çıkarımını yapmakta ve akabinde Hıristiyanların bu kıyası kabul etmediklerini bildirmektedir. ${ }^{22}$

Duran'dan önce de Yahudi polemikçiler Teslis'e dair çok çeşitli itirazlar yapmıştır. Lasker'e göre Duran'ı bu noktada farklı kılan husus Teslis'i mantık ilkelerine tabi tutan ilk polemikçi olmasıdır. Bununla birlikte argümanlarının bazıları yeterince güçlü bulunmamıştır. Zira hem Baba'nın hem de Oğul'un Tanrı olduğundan yola çıkılan bir kıyasın sonucunda, onların aynı oldukları değil, Baba ile Oğul'un aynı öze/töze sahip olduğu ortaya çıkar. Kaldı ki zaten Hıristiyanlar onların aynı tanrısal öze sahip üç ayrı şahıs olduğunu kabul etmektedirler. ${ }^{23}$ Bu minvalde Hıristiyanlar rahatlıkla 'Baba, Oğul ve Kutsal Ruh güç ve mükemmellik açısından eşit olsa da Baba Oğul'dan kendisiyle kurduğu ilişki bakımından farklı, Oğul da Baba'dan farklıdır' diyebilmektedirler (Kutsal Ruh için de bu durum aynıdır). Bununla beraber Aquinas ve diğer pek çok Hıristiyan teolog Teslis'i anlaşılabilir kılmak için sayısız izahlarda bulunmuşlarsa da Teslis'in akılla tam olarak kavranılamayacağı noktasında hepsi hemfikirdir. Bu bakımdan Teslis doktrini Hıristiyanlığın erken dönemlerinden itibaren hem kendi içlerinde hem de diğer tevhidi geleneğe sahip dinler/din müntesipleri tarafından sıklıkla eleștirilere maruz kalmıştır. ${ }^{24}$ Dolayısıyla Duran'ın savunma argümanları yeterince güçlü olmasa da problemin tespitindeki metodu ve istikameti açısından eleştirisinin oldukça isabetli olduğu söylenebilir.

Duran'ın mektubunda işlediği diğer bir husus Hıristiyan gelenekteki aslî günah doktrini ve enkarnasyon öğretisiyle ilgilidir. Hıristiyan öğretiye göre, Adem'in yaratılışın başlangıcında işlemiş olduğu günahın büyüklüğü nedeniyle bu günahın sonuçları bütün insanlığa sirayet etmiştir. ${ }^{25}$ Söz konusu öğretiyle ilgili en ilginç kısımlardan biri, bu yaklaşımın Kutsal Kitaba dair ilk referansının İsa'ya değil Pavlus'a ${ }^{26}$ dayandırılmasıdır. ${ }^{27} \mathrm{Bu}$ hususta Duran, David'den, asırlar boyunca Yaratılış

189; Kozodoy, The Secret Faith of Maestre Honoratus, 117.

22 Kobler, "Be Not Like Fathers", 278, 279.

23 Lasker, Jewish Philosophical Polemics against Christianity in the Middle Ages, 90, 91.

24 Muhammet Tarakçı, St. Thomas Aquinas (İstanbul: İz Yayıncılık, 2006), 130; Mahmut Aydın, Hristiyanlık: Tarih, İnanç ve Uygulama (İstanbul: Ketebe Yayınevi, 2021), 322, 323.

25 Bu meseleye dair Hıristiyanlık tarihinde farklı seslerin olduğu da bilinmelidir. Pelagius'a (öl. 418) göre Adem'in günahı diğer insanlara sirayet etmemiştir ve yalnızca kendisini bağlamaktadır. Hıristiyan gelenekte (Augustin'in tesiriyle) yer aldığı şekliyle hem Adem'in günahının bütün insanlara sirayet ettiğini söylemek hem de İsa'nın çarmıha gerilmesi ile tüm insanlığın değil de bazı insanların (İsa’ya inananların) kurtulabileceğini iddia etmek sorunlu bir yaklaşımdır. Ayrıntılı bilgi için bk. Dursun Ali Aykıt, “Pelagianizm'in Tarihi ve Öğretileri”, İstanbul Üniversitesi İlahiyat Fakültesi Dergisi 22 (2010), 188, 193.

26 “Günah bir insan aracılığılla, ölüm de günah aracılı̆̆ıyla dünyaya girdi. Böylece ölüm bütün insanlara yayıldı. Çünkü hepsi günah işledi.” Romalılar 5:12. 
bahsini okuyup orada geçen meseleleri/kavramları (ilk insan çifti, dört nehir, bilme ağacı, yılan gibi) anlamak için kafa yoran atalarının yolundan gitmemesini ister. Bununla atalarının boşa yorulduğunu, sonradan gelenlerin asıl "gerçeğe" vakıf olduğunu ima etmektedir. Ona göre Hıristiyanlar Adem'in günahını daha da arttırmış ve üstelik onu kurtarıcıya (İsa) muhtaç hâle getirmiştir. Duran, bu noktada, Hıristiyanlıktaki aslî günah anlayışı ve İsa ile bu günahın kefaretinin ödenmesi ögretisine herhangi bir eksiltme ya da ilave yapmadan meseleyi olduğu gibi aktarmaktadır. Aslî günah öğretisinin ve kurtuluştaki İsa rolünün, gerçek kurtarıcı İsa'ya değil Pavlus'a dayandırılmasına da ima yoluyla bir göndermede bulunmaktadır. Duran, Hıristiyanlıktaki İsa merkezli kurtuluş öğretisinin Pavlus tarafından geliştirildiğini bilmektedir. Dolayısıyla kurtuluşun baş aktörünün ve asıl fedakârlığı yapan kişinin bu 'kıymetli' öğretiden hiç bahsetmemiş olmasını yadırgadığı belli belirsiz hissedilmektedir. Fakat netice itibariyle David'den bu gizeme sıkı sıkıya sarılmasını ve koşulsuz iman etmesini istemektedir. Belli ki Duran nezdinde salt iman dişında bu öğretiye ikna edilmenin başka bir yolu yok gibi görünmektedir. ${ }^{28}$

Mektupta, aslî günahın kaldırılması hususunda da birtakım ayrıntılar mevcuttur. Duran, Hıristiyanlar nezdinde, Kutsal Kitapta yazmıyor olsa da İsa ile birlikte, aslî günahtan kurtuluşun sağlandığına, fakat aslî günaha karşılık verilen lanetlerin/cezaların hâlâ devam ettiğine dikkat çekmektedir. Bu noktada Hıristiyanların İsa Mesih'in kurtarıcı (bilhassa aslî günahtan) rolünden ne anladıkları izaha muhtaç gibi görünmektedir. Augustin'in (öl. 430) aslî günahı anlama biçimi genel Hıristiyan öğretiyi şekillendirmiştir. Bu öğretiye göre, başlangıçta ölümsüz olan Adem'e işlediği günah nedeniyle ölüm cezası verildiğine inanılmaktadır. Orta Çağ Hıristiyan teoloğu Aquinas (öl. 1274) yeryüzünde dünyaya gelen herkesin ölmesini, bütün insanlı̆̆ın bu günahtan nasibini aldığına bir işaret olarak değerlendirmektedir. ${ }^{29}$ İşlenen her günahın bir cezası olmasından hareketle, bu günahın da bir bedeli olmalıdır. Hıristiyanlara göre bu bedeli ödeyecek kişi, sıradan bir insan olmamalı fakat günahın aslı bir insana (ve tüm insanlığa) ait olduğu için bedeli ödeyenin de bir insanî yönü olması gerekmektedir. Ayrıca hem Tanrı'nın insanlığın kurtuluşuna dair planının kusursuz gerçekleşmesi hem de bedeli ödeyenin bu fedakârlığı yapabilecek güçte olması gerektiği için bu kurbanın da kusursuz olması (bir Tanrı olmas1) gerekmektedir. Bu yüzden Tanrı'nın kendi oğlunu yeryüzüne göndermesiyle kurtuluşa dair ilk plan gerçekleştirilmiştir. Bununla birlikte İsa'nın çarmıha gerilmesi ile pek çok fayda sağlanmış ve günahın izi temizlenmiş (yalnızca İsa'ya inananlar için) olsa da kurtuluş tam olarak gerçekleşmemiştir. Günahın beraberinde getirdiği lanetler/cezaların (bilhassa ölüm) tümden yok edilmesi için, İsa Mesih'in

27 Muhammet Tarakçı, “St. Thomas Aquinas’a Göre Aslî Günah”, Uludağ Üniversitesi İlahiyat Fakültesi Dergisi 15/1 (2006), 308, 309.

28 Kobler, "Be Not Like Fathers", 278.

29 Tarakçı, “St. Thomas Aquinas'a Göre Aslî Günah”, 311; Aykıt, “Pelagianizm'in Tarihi ve Öğretileri”, 188, 189. 
ikinci kez gelmesi gerekmektedir. Bir sonraki gelişinde o, bütün ölüleri dirilterek onları bu cezadan kurtaracak ve kurtuluş planı tamamlanacaktır. ${ }^{30}$

Duran'ın, Baba Tanrı'nın aslî günahtan kurtuluş için bulduğu enkarnasyon çözümünü de makul bulmadığ görülmektedir. Bu hususta David'e, Malaki'den ${ }^{31}$ referansla Tanrı'nın cisimsizliğine, değişmezliğine inanan atalarına da benzememesini salık vermektedir. Çünkü David'in Hıristiyan inancı gereği Tanrı'nın (Baba'nın) insanlığın kurtuluşu için kurban etmek üzere üç şahsından birini (oğlunu) enkarne ettiğine inanmaması hâlinde Cennet'e gidemeyeceğini belirtmektedir. Üstelik böyle büyük bir fedakârlık yaptığı için ne kadar şükretseler az olduğunu dile getirmektedir. Duran, insanlığın kurtuluşu için böyle bir çarenin yalnızca her şeye gücü yeten bir Tanrı tarafından bulunabileceğini söyleyerek, alaycı bir dille bu öğretiyi ve bir Tanrıya layık görülen tavrı/kararı eleştirmektedir. ${ }^{32}$

Duran'ın Hiristiyanlığa yönelttiği temel eleştirilerinden bir diğeri yine enkarnasyonla bağlantılı olarak İsa'nın (bir Tanrı'nın) bakire bir kadından doğduğuna dair Hıristiyan yaklaşımına ilişkindir. Fakat bu bahiste, meselenin imkânına/imkânsızlığına temas etmeden, yalnızca öğretinin dayandırıldığı referans eleştirilmektedir. ${ }^{33}$ Bakireden doğuma ilişkin Kanonik İncillerdeki en erken referans, İsa'nın Mesihliğine delil mahiyetinde Yeşaya'daki bir pasajın kullanıldığı Matta İncili'nde geçmektedir. Yeşaya'da geçen “Bundan ötürü Rab'bin kendisi size bir belirti verecek: İște, genç kadın gebe kalıp bir oğul doğuracak; adını İmmanuel koyacak' (7:14) ifadesinde geçen kadın (İbranicesi alma) kelimesi Matta İncili'nde Grekçeye çevrilirken bakire anlamına gelecek bir kelime (parthenos) ile karşılan$m ı s^{34}$ ve beklenen kurtarıcının bakireden doğduğuna dair bir öğreti şekillenmiştir. ${ }^{35}$ Duran bu çıkarımın hatalı olduğunu iki gerekçe üzerinden temellendirmektedir. Illk olarak çeviri kaynaklı bir sorunun olduğu bir başka Tanah cümlesiyle ortaya çımaktadır. Süleyman'ın Meselleri'nde alma kelimesinin geçtiği bir pasaj $1^{36}$ referans göstererek, bu ifade ile bakirenin değil genç kadının kastedildiğini vurgulamıştır. İkinci olarak ise Yeşaya'da bahsi geçen genç kadının (yaklaşık olarak beş asır önce)

30 Tarakçı, St. Thomas Aquinas, 223, 224; Kemal Polat, "Hıristiyan Kurtuluş Öğretisinde İsa Vasıtasıyla Kurtuluş”, EKEV Akademi Dergisi 10/27 (2006), 187, 188, 190, 193, 197.

31 “Ben RAB'bim, değişmem. Siz bunun için yok olmadınız, ey Yakup soyu!" Malaki 3:6.

32 Kobler, "Be Not Like Fathers", 278.

33 Kobler, "Be Not Like Fathers", 278.

34 "Bütün bunlar, Rab’bin peygamber aracilığıyla bildirdiği şu söz yerine gelsin diye oldu: 'Isste, kı/bakire gebe kalıp bir oğul doğuracak; adını İmmanuel koyacaklar.' İmmanuel, Tanrı bizimle demektir." Matta 1:22-23. Günümüz Kutsal Kitap Türkçe çevirilerinde 'bakire' kelimesi geçmemekte, yalnızca 'kız' şeklinde yazılmaktadır.

35 Günay Tümer, Hiristiyanlikta ve İslamda Hz. Meryem (Ankara: Türkiye Diyanet Vakfı Yayınları, 2021), 123, 124.

36 "Kartalın gökyüzünde, yılanın kayada, geminin denizde izlediği yol ve erkeğin genç kızla (alma) tuttuğu yol” Süleyman'ın Meselleri 30:19. 
Kral Ahaz zamanında yaşadı̆̆ını vurguladıktan sonra, kastedilen kişinin Meryem ve doğacak çocuğun da İsa olamayacağını belirterek Hıristiyan öğretinin dayandığı temel argümanı çürütmeye çalışmaktır. ${ }^{37}$

Yahudi polemikçilerin Hıristiyanlık eleştirilerinde diğer İncillerden daha fazla Matta'yı tercih etmeleri dikkat çekici bir durum olarak karşımıza çıkmaktadır. Bu başvurunun birtakım gerekçeleri olduğu düşünülmektedir. En önemli gerekçelerden biri Matta İncili'nde, diğer İncillerden daha fazla Tanah'tan referans kullanılmasıdır. Bu hâliyle, Tanah'taki asırlardır gelmesi beklenen kurtarıcının İsa Mesih olduğunu kanıtlamak üzere hazırlanmış bir metin görünümündedir. Bir nevi Tanah’taki İsrail tarihi ile İsa arasında bir köprü işlevi görmektedir. Bu bakımdan hem Hıristiyanların kendi dinlerini meşrulaştırma adına sıklıkla (ve diğer İncillere kıyasla daha fazla) kullandıkları, hem de Yahudilerin bilhassa İsa'nın Mesihliğini (ve tabii ki uluhiyetini) reddetmede en sık müracaat ettikleri metin hâline gelmiştir. İsa'nın bir insandan çok daha fazlası olduğuna, yani ulûhiyetine dair kullanılan referans (alma-bakire), Yahudi polemikçilerce sıklıkla ve aynı gerekçeyle (çeviri hatası) reddedilmiştir. Dolayısıyla Duran'ın hem Matta İncili'ni referans alması hem de bakire doğumuna ilişkin pasajı hedef alması yeni bir durum değildir. ${ }^{38}$

Duran'ın mektubunda sorguladığı diğer bir husus Hıristiyanların sakrament olarak kabul ettikleri Evharistiya ayiniyle ilgilidir. Duran'ın eleştirileri ile paralel şekilde sakramentin uygulanış şekli ve içerdiği teolojik anlamlar Hıristiyanlar arasında da ihtilaflı bir konudur. İncillerde geçen İsa'nın son akşam yemeği anısına düzenlenen bu ritüelde, bilhassa İsa'nın havarilere önlerinde bulunan ekmeği, kendi bedeni/eti; şarabı ise kanı olarak takdim etmesi ${ }^{39}$ meselesi, ciddi fikir ayrılıklarına neden olmuştur. Ayin esnasında rahibin dua ederek verdiği ekmek ve şarabın İsa'nın bedeni ve kanına dönüşüp dönüşmeyeceği uzun yıllar boyunca tartışılmıştır. Katolik Kilisesi yaşanan tartışmaları IV. Lateran Konsili (1215) ile Trent Konsili’nde (1545-1563) alınan kararlarla netleștirmiş ve ayin esnasında inananların yediği ekmeğin ve şarabın, İsa'nın bedeni ve kanına dönüştüğüne karar vermiştir. Bu dönüşüme inanmayanların lanetleneceği düşünülerek meselenin ciddiyeti vurgulanmaktadır. Ortodoks ve Protestanlar ise bu dönüşümü kabul etmemektedirler. ${ }^{40}$

Duran, töz dönüşümünün fizik ve metafizik ilkelerini ihlâl eden türden bir inanç olduğuna dikkat çekmektedir. İsa Mesih'in, Tanrı'nın sağ yanında sabit dururken,

37 Kobler, "Be Not Like Fathers", 278.

38 Christoph Ochs, Matthaeus Adversus Christianos: The Use of the Gospel of Matthew in Jewish Polemics against the Divinity of Jesus (Tübingen, Germany: Mohr Siebeck, 2013), 8-12.

39 Matta 26:26-28; Markos 14:22-24; Luka 22:19, 20.

40 Tarakçı, St. Thomas Aquinas, 207-211; Muhammet Tarakçı, Protestanlıkta Sakramentler (Bursa: Emin Yayınlar1, 2012), 148-150; A. Hikmet Eroğlu, “Ekmek-Şarap Ayini (Evharistiya) Konusunda Katolikler ve Protestanlar Arasındaki Anlayış Farklılıkları”, Ankara Üniversitesi İlahiyat Fakültesi Dergisi 39/1 (1999), 439-443; Aydın, Hristiyanlı: Tarih, İnanç ve Uygulama, 342-345. 
ayin esnasında rahibin duası ile sunağa inerek hareket kazanması ve rahibin önündeki ekmeğin/bisküvinin rahibin dudaklarından dökülen dua sonrasında tözsel bir değişikliğe uğraması hakikatte fizik ve metafizik kurallarına göre imkânsızdır. Bununla birlikte Duran, David'den, bu inanılması güç ve imkânsız gibi görünen şeyleri kabul etmesini ve her şeye gücü yeten bir Mesih'e tabi olduğunu aklından çıkarmamasını istemektedir. ${ }^{41}$

Duran, Hıristiyanların irrasyonel bulduğu inançlarına değinmenin yanı sıra Hıristiyanların mevcut durumlarına ilişkin de bazı hususları eleştirmektedir. Bu çerçevede değindiği konulardan biri Yahudi şeriatına bağlılık meselesidir. Ataları peygamberlerden aldığı mesajlarla titizlikle bu kuralları muhafaza etmişler ve ilk peygamberden son peygambere kadar her biri şeriata uyma ve onu çocuklarına aktarma hususunda uyarılmışlardır. Fakat artık kalben de Hıristiyanlı̆̆ı benimsemiş olan David'in şeriattan kaynaklanan mitzvaları (şabat, kaşer, evlilik gibi emir ve yasaklar) yerine getirmesine veya kendi evlatlarına bu kuralları anlatmasına gerek kalmamıştır. ${ }^{42}$ Duran bu noktada havarilerin ve İsa'nın şeriat konusundaki tutumuna dikkat çekerek, Hıristiyanlar ile bu dinin kurucusu ve ilk takipçileri arasındaki çelişkili tavrı mevzubahis etmektedir. Havarilerin Yahudi şeriatını devam ettirdiklerini, Elçilerin İşleri kitabın ${ }^{43}$ delil göstermek suretiyle aktarmaktadır. Fakat bu örnekleri vermeye gerek olmadığını, çünkü Mesih'in (İsa'nın) bizzat kendisinin şeriatın devamlılığına işaret ettiğini ${ }^{44}$ savunmaktadır.

Duran'ın dönemin Papalık makamına dair eleștirilerinin olduğu da görülmektedir. Mektubun yazıldığı tarihler Katolik Kilisesi'nin zor dönemlerden geçtiği bir sürece denk gelmektedir ve mektubundan anlaşıldığı üzere Duran da bu husustaki detaylara hâkimdir. David, kendisini yeni dinine isındıran hocası Pavlus'u mektubunda övmüş olmalıdır ki Duran Kilise'nin bu sürecini mevzubahis ederken Pavlus üzerinden meseleyi açmaktadır. David'in Pavlus'u neredeyse Papa kadar yücelttiğini söylemekte, fakat onun Roma'ya mı yoksa Avignon'a mı gitmesi gerektiğinden emin olamadığından bahsetmektedir. ${ }^{45}$ İma ettiği husus, Kilise içerisindeki bölünmedir. O dönemde Roma'da ve Avignon'da iki ayrı Papa bulunmakta ve her ikisi de kendisinin gerçek Papa olduğunu iddia etmekteydi. ${ }^{46}$ Duran, Katolikler arasında

41 Kobler, "Be Not Like Fathers", 279; Kozodoy, The Secret Faith of Maestre Honoratus, 117.

42 Kobler, "Be Not Like Fathers", 280.

43 Elçilerin İşleri 15. Bapta, başka milletlerden İsa'ya tabî olanları, Yahudilerin yükümlü oldukları şeriat kurallarıyla sorumlu tutmaya gerek olup olmadığı tartışılmaktadır. Netice itibariyle putlara sunulan ve boğularak öldürülen hayvanların, kanın tüketimi ve fuhuş dışında geri kalan bütün kurallardan muaf tutulduklarına kanaat getirilmiştir. Duran bu pasajla kuralların seyreltilmesi meselesinden çok, havarilerin de şeriata bağlı olarak yaşadığı gerçeğine dikkat çekmek istemiş olmalıdır.

44 “Kutsal Yasa'yı ya da peygamberlerin sözlerini geçersiz kılmak için geldiğimi sanmayın. Ben geçersiz k1lmaya değil, tamamlamaya geldim.” Matta 5:17.

45 Kobler, "Be Not Like Fathers", 280, 281.

46 The Great Western Schism/Büyük Batı Bölünmesi olarak tarihe geçen bu süreç 1378-1417 yılları 
Papa'nın konumu ve ona yüklenen anlam bakımından oldukça sorunlu olan bu hususu ve yaşanan süreci David'e hatırlatarak yeni dinini küçümsemektedir.

Tarihsel kayıtlar Duran'ın yaşadı̆̆ı dönemlerde İber Yarımadası'ndaki Yahudilerin, pek çok ilme aynı anda vakıf olduklarını ve entelektüel bir toplum yapısı içerisinde hayatlarını sürdürdüklerini göstermektedir. David de hem mensubu olduğu aile (kraliyet soyu) hem de aldığı eğitimler (tıp vs.) gereği kendisini iyi yetiştirmiş birisidir. Dolayısıyla Duran'ın mektubunda sürekli yaptığı 'atalarına benzeme' vurgusu (hakikatte David'i soyuna ihanet etmek iması taşımaktadır) yalnızca Yahudi atalarına ihanet şeklinde değil, aynı zamanda kendi soylu ailesine karşı isyan olarak da algılanabilir. ${ }^{47}$ Bunu destekleyecek şekilde mektubun sonlarına doğru Duran, David'e, artık babasının adını/soyadını kullanmaması gerektiğini, onun mezarında David'e ve seçtiği yeni yola lanet ettiğini ve mühtedi bir oğlu olmasındansa hiç oğlu olmamasını tercih edeceğini belirtir. Ayrıca yeni dindaşlarının da kendisine düşman kesildikleri vakitlerde onu aşağılamak için birtakım lakaplar takacaklarını belirterek, seçtiği yolda da rahat edemeyeceğini ve karşılaşabileceği zorlukları hatırlatmaktadır. ${ }^{48}$

Duran, mektubunun sonunda David'in Hıristiyanlığa davetini kabul etmeyeceğini ve Mesih'in geleceği vakte kadar imanını gururla taşıyacağını bildirmektedir. David'in doğru yola, yani Yahudiliğe geri dönmesi hâlinde ise kendisini yeniden bir kardeş ve sevgili oğul gibi kabul edeceğini belirtmektedir. ${ }^{49}$ Mektubun bu kısmı belki de alayın, hicvin olmadığı yegâne kısımdır. Duran hem kendi tavrını ciddiyetle ortaya koymuş hem de David'e geri dönmesi için samimi bir çağrıda bulunmuştur. Mektubun David'e ulaşıp ulaşmadığı bilinmemektedir, fakat günümüze ulaşabilecek kadar çok kopyalanmasına bakılacak olursa David'in mektuptan haberdar olması oldukça muhtemeldir.

arasına denk gelmektedir. Bu süre zarfında iki (bir süre sonra üç) Papa ile Batı Hıristiyanlığı yönetilmeye çalışılmıştır. Ciddi anlamda kutuplaşmaların ve Papalar arası rekabetin yaşandığı bu dönemde inanırların hangi Papa'ya tabi olacakları hususunda kafa karışıklıkları yaşadıkları görülmektedir. Sürecin arka planı, Batı Hıristiyanlı̆̆ına tesirleri ve çözüm sürecine dair ayrıntılı bilgi için bk. Joelle Rollo Koster, Avignon and Its Papacy 1309-1417 (New York: Rowman \& Littlefield Publishers, 2015), 239-286.

47 E. Gutwirth, "Religion and Social Criticism in Late Medieval Rousillon: An Aspect of Profayt Duran's Activities", Michael: On the History of the Jews in the Diaspora, ed. Shlomo Simonsohn vd. (Tel Aviv: Diaspora Research Institute, 1991), 144, 145; Kozodoy, "The Hebrew Bible as Weapon of Faith in Late Medieval Iberia: Irony, Satire and Scriptural Allusion in Profiat Duran's Al Tehi ka-Avotekha”, 186.

48 David'in kendisine söylenenlerden dolayı utanmış ya da aşağılanmış hissetse bile bunu umursamamasını, zira kurtuluşun buna "değer” olduğunu hatırlatmaktadır. Kobler, "Be Not Like Fathers”, 280, 281.

49 Kobler, “Be Not Like Fathers”, 281, 282. 


\section{Sonuç}

İnanca dair konuların akıl ve mantık yoluyla ele alınıp alınamayacağı veya bunun ne dereceye kadar yapılabileceği asırlardır tartışılagelmiştir. Bununla birlikte din müntesipleri nadiren kendi dinlerini fakat ağırlıklı olarak muhalif gördükleri dinleri irrasyonel oldukları gerekçesiyle eleştirmekten geri durmamışlardır. Duran da mektubunda bu karşılaştırmayı yapmış ve Hıristiyanlığı Yahudiliğe kıyasla daha irrasyonel bularak ironik bir üslupla eleștirmiștir. Eleștireceği hususları belirlerken yalnızca akıl ve mantık ilkeleriyle çelişenleri değil, Hıristiyanlar arasında da ihtilaflı olan konuları tercih etmiştir. Dolayısıyla metninde iki yönlü bir avantaj elde etmiştir. Bu eser felsefî ilkelere başvurarak eleştirme yöntemi bakımından ilk/özgün reddiyeler arasında zikredilmektedir. İçerisinde yer alan eleştirilerin büyük çoğunluğu tutarlı olmasına rağmen, argümanların bir kısmı yeterince güçlü bulunmamıştır. Aynı hususta çok daha güçlü argümanlar sunma imkânı varken, daha azıyla yetinildiğini söylemek mümkündür. Bu durumun donanım ya da bilgi eksikliğinden değil, mektup gibi hacmi çok geniş olmayan bir yazı türünün tercih edilmesinden kaynaklanmış olması daha muhtemel görünmektedir.

Mektubun üslup ve kurgusu Hiristiyanllğı kabulünden dolayı David'i tebrik ve teşvik etme görünümünde olsa da aslında bu kurgunun/üslubun, David ile alay etme ve onu aşağılama maksadıyla inşa edildiği bellidir. Yazarın bu tercihi, öncelikle kendi kimliğini/dinini (konverso/marrano) gizleme dürtüsünden kaynaklanmış olabilir. Döneme dair araştırmalar, nispeten bir rahatlık ortamından bahsediyor olsa da arkadaşıyla birlikte Filistin'e dönme isteği bazı endişelerin varlığına işaret etmektedir. Buna bağlı olarak mesajın kafa karışıklı̆̆ yaratarak iletilmek istenmiş olması da muhtemeldir. Fakat bu noktada akla böyle bir durumda mektuptan sonraki reddiye çalışması olan ve Hıristiyanlığı açıktan ve detaylıca eleştirdiği Kelimmat ha-Goyim'i nasıl yazabildiği sorusu gelmektedir. Üslup tercihindeki muhtemel diğer bir neden ise, bilhassa etkilenmiş olabileceği Latince mektup rivayeti dikkate alındığında, okuyucuyu (Yahudilikten Hıristiyanlığa geçmiş/geçecek kişi) daha fazla etkileme adına tercih edilmiş olmasıdır. Muhatabın sinir uçlarına dokunacak şekilde hazırlanan bu kurgunun (hem alaycı üslup hem de Yahudilik-Hıristiyanlık karşılaştırması) okuyucuyu sıradan bir Hıristiyanlık eleştirisini okumaktan çok daha fazla rahatsız edeceği düşünülmüş olabilir.

Duran mektubunu Yahudi kutsal kitabını, şeriatını, İbranice'yi ve Yeni Ahit'i bilen bir mürtede hitaben yazmıştır. Mektup reddiye literatüründe kendine yer bularak daha bilinir ve popüler hâle gelmiş olsa da Yahudilikten Hıristiyanlığa geçmiş veya geçmeyi düşünen Yahudilere hitap etmeye devam etmiştir. Netice itibariyle Duran'ın kendi kişisel deneyiminden yola çıkarak hazırlanan bu metin günümüze kadar gelebilmiş ve dönemin Yahudi-Hıristiyan ilişkilerine hem dinî hem de sosyal açıdan bir bakış imkânı sağlamıştır. 


\section{Kaynakça}

Aydın, Mahmut. Hristiyanlık: Tarih, İnanç ve Uygulama. İstanbul: Ketebe Yayınevi, 2021.

Aykıt, Dursun Ali. “Pelagianizm'in Tarihi ve Öğretileri”. İstanbul Üniversitesi İlahiyat Fakültesi Dergisi 22 (2010), 175-196.

Baer, Yitzhak. A History of the Jews in Christian Spain, Vol. 2: From the Fourteenth Century to the Expulsion. çev. Louis Schoffman. Skokie: Varda Books, 2001.

Emery, Richard W. "New Light on Profayt Duran 'The Efodi”'. The Jewish Quarterly Review 58/4 (1968), 328-337.

Eroğlu, A.Hikmet. "Ekmek-Şarap Ayini (Evharistiya) Konusunda Katolikler ve Protestanlar Arasındaki Anlayış Farklılıkları”. Ankara Üniversitesi İlahiyat Fakültesi Dergisi 39/1 (1999), 439-453.

Gutwirth, E. "Religion And Social Criticism In Late Medieval Rousillon: An Aspect of Profayt Duran's Activities". Michael: On the History of the Jews in the Diaspora. ed. Shlomo Simonsohn vd. 135-156. Tel Aviv: Diaspora Research Institute, 1991.

Kayserling, Meyer. "Profiat Duan". Jewish Encyclopedia. Erişim 1 Aralık 2021. https://www.jewishencyclopedia.com/articles/5366-duran.

Kobler, Franz. "Be Not Like Fathers". Letters of Jews through the Ages: From Biblical Times to the Middle of the Eighteenth Century. 276-282. New York: East and West Library, 1978.

Koster, Joelle Rollo. Avignon and Its Papacy 1309-1417. New York: Rowman \& Littlefield Publishers, 2015.

Kozodoy, Maud. "The Hebrew Bible as Weapon of Faith in Late Medieval Iberia: Irony, Satire and Scriptural Allusion in Profiat Duran's Al Tehi ka-Avotekha". Jewish Studies Quarterly 18/2 (2011), 185-201.

Kozodoy, Maud. The Secret Faith of Maestre Honoratus: Profayt Duran and Jewish Identity in Late Medieval Iberia. Philadelphia: University of Pennsylvania Press, 2015.

Lasker, Daniel J. Jewish Philosophical Polemics Against Christianity in the Middle Ages. Oxford: Littman Library of Jewish Civilization, 2007.

Meral, Yasin. İbrahim Müteferrika Öncesi İstanbul'da Yahudi Matbuatı (1493-1729). Ankara: Divan Kitap, 2016.

Ochs, Christoph. Matthaeus Adversus Christianos: The Use of the Gospel of Matthew in Jewish Polemics Against the Divinity of Jesus. Tübingen, Germany: Mohr Siebeck, 2013. 
Polat, Kemal. "Hıristiyan Kurtuluş Öğretisinde İsa Vasıtasıyla Kurtuluş". EKEV Akademi Dergisi 10/27 (2006), 183-202.

Profiat Duran. Kitvey Pulmus Le-Profiat Duran. ed. Frank Talmage. Kudüs: The Zalman Shazar and The Dinur Center, 1981.

Raymond, Irwing R. “D’Ailly's ‘Epistola Diaboli Leviathan'”. Church History 22/3 (1953), 181-191.

Salihoğlu, Mahmut. "Marranolar ve Dini İnançları". EKEV Akademi Dergisi 15/49 (Güz 2011), 105-115.

Szpiech, Ryan. "Between Court and Call: Catalan Humanism and Hebrew Letters". eHumanitsa-IVITRA 1 (2012), 168-184.

Şengül, Fatma Seda. “Yahudi Düşünür Profiat Duran'ın İsa'nın Ulûhiyetine Dair Eleştirileri”. Oksident 1/1 (2019), 79-100.

Talmage, Frank. “The Polemical Writings of Profiat Duran”. Immanuel 13 (1981), 6985.

Tarakçı, Muhammet. Protestanlıkta Sakramentler. Bursa: Emin Yayınları, 2012.

Tarakçı, Muhammet. St. Thomas Aquinas. İstanbul: İz Yayıncılık, 2006.

Tarakçı, Muhammet. “St. Thomas Aquinas'a Göre Aslî Günah”. Uludağ Üniversitesi İlahiyat Fakültesi Dergisi 15/1 (2006), 307-318.

Trautner-Kromann, Hanne. Shield and Sword: Jewish Polemics against Christianity and the Christians in France and Spain from 1100-1500. Tübingen: Mohr Siebeck, 1993.

Tümer, Günay. Hiristiyanlıkta ve İslamda Hz. Meryem. Ankara: Türkiye Diyanet Vakfı Yayınları, 2021. 


\section{An Ironic Letter in The Anti-Christian Jewish Polemic Tradition: Al Tehi Ka-Avotekha (Be Not Like Fathers)}

\section{Extended Summary}

The Judeo-Christian polemic tradition has a long history. This study deals with Profiat Duran's treatise Al Tehi Ka-Avotekha, which has an important place in style and content in polemic literature. It has been debated for centuries whether the issues of faith can be evaluated through reason and logic. However, adherents of religion did not refrain from criticizing the religions they saw as opposing on the grounds that they were irrational. Duran wrote his letter in which he compares Judaism and Christianity to David Bonet Bonjorn.

The introduction mentions Profiat Duran's life, his baptism, and the journey of his letter from past to present. Profiat Duran lived in the 14th century, and his Hebrew name was Isaac ben Moses ha-Levi. He wrote two polemical works against Christianity. The first is Al Tehi Ka-Avotekha, which he wrote in letter form, and the second is Kelimmat ha-Goyim. His Al Tehi Ka-Avotekha has been evaluated in our study. We chose Duran and his work as the subject of study for two reasons. The first is that he is a Jewish writer who is baptized under compulsion. For this reason, discussions about Duran's baptism are also emphasized in the study. The second point is that Al Tehi Ka-Avotekha differs from other polemics in content and method. Duran seems to be praising the religion of the other party in his work. However, he actually criticizes them because he prefers ironic language. In this respect, his way of criticizing provided the birth of a different type in the Jewish polemic tradition. Some researchers think that Duran may have been influenced by a Latin letter (Pierre d'Alilly's letter). The first person to publish Duran's letter was Isaac Akrish. It was printed in one of the Jewish printing houses in Istanbul (Solomon and Joseph Jabez Press) in 1577 in a collection called Iggeret Ogeret.

The first part of the article gives detailed information about the style and content of the letter. Two phrases are repeated in the letter: Al tehi ka-avotekha (be not like fathers) and at lo ken (not so thou). Before each subject he mentions in his letter, Duran tells his Jewish ancestors' practices for centuries and then warns David not to be like them. Afterward, he offers false praise to David's and Christians' understanding of salvation based on pure faith, which violates the principles of reason, logic, and philosophy. The style in the letter may have primarily resulted from the author's urge to hide his identity/religion. This style may also have been preferred to impress the reader more. It may have been thought that this fiction (both the sarcastic style and the Judaism-Christianity comparison), which was prepared in a way that would touch the nerves of the addressee, would be more disturbing than an ordinary Christian critique. 
In the second part of the article, Duran's criticisms against Christianity are evaluated. In Duran's letter, it is seen that he mainly preferred the subjects that contradict the principles of reason and logic and on which Christians are in dispute. He criticizes the Trinity for contradicting the principles of logic and mathematics. Some of his arguments on this issue were found weak. He also criticizes the teachings of original sin and incarnation. He finds it strange that Adam's sin spread to all people. He does not see the plan of salvation provided with Jesus as sufficient. He also opposes the idea that Jesus was born of a virgin in connection with the incarnation. In this regard, he draws attention to the translation error made in the Gospel of Matthew. Duran also criticizes the theological meaning that Catholics ascribe to the eucharist rite. He claims that the conversion of the bread and wine given by the priest into the body and blood of Jesus is impossible within the framework of the laws of physics and metaphysics. After emphasizing that Jesus and his apostles lived by the Jewish law, but the Christians abandoned it, he criticizes the current status of Papal authority in the Catholic Church. In the last part of the letter, Duran rejects David's invitation to Christianity. However, he states that if David converts to Judaism, he will accept himself as a brother again.

As a result, this text, which was prepared based on Duran's personal experience, has survived to the present day and provided an opportunity to look at the JudeoChristian relations of the period from both a religious and social point of view.

Keywords: History of Religions, Al Tehi Ka-Avotekha, Be Not Like Fathers, Hebrew letters, Profiat Duran, Polemic, Jewish-Christian. 